\title{
Carbon isotope fractionation for cotton genotype selection
}

\author{
Giovani Greigh de Brito(1), Nelson Dias Suassuna ${ }^{(2)}$, Valdir Diola(3), \\ Valdinei Sofiatti( ${ }^{(2)}$, Carlos Ducatti( ${ }^{(4)}$, Evandro Tadeu da Silva ${ }^{(4)}$ and Camilo de Lelis Morello ${ }^{(2)}$
}

\begin{abstract}
(1)Embrapa Clima Temperado, Caixa Postal 403, CEP 96010-971 Pelotas, RS, Brazil. E-mail: giovani.brito@embrapa.br (2)Embrapa Algodão, Núcleo Cerrado, Caixa Postal 179, CEP 75375-000 Santo Antônio de Goiás, GO, Brazil. E-mail: nelson.suassuna@embrapa.br, valdinei.sofiatti@embrapa.br, camilo.morello@embrapa.br ${ }^{(3)} / n$ memoriam ${ }^{(4)}$ Universidade Estadual Paulista, Instituto de Biociências, Centro de Isótopos Estáveis Ambientais em Ciências da Vida, Caixa Postal 510, CEP 18608-000 Botucatu, SP, Brazil. E-mail: ducatti@pq.cnpq.br, evandro@ibb.unesp.br
\end{abstract}

\begin{abstract}
The objective of this work was to evaluate the carbon isotope fractionation as a phenomic facility for cotton selection in contrasting environments and to assess its relationship with yield components. The experiments were carried out in a randomized block design, with four replicates, in the municipalities of Santa Helena de Goiás (SHGO) and Montividiu (MONT), in the state of Goiás, Brazil. The analysis of carbon isotope discrimination $(\Delta)$ was performed in 15 breeding lines and three cultivars. Subsequently, the root growth kinetic and root system architecture from the selected genotypes were determined. In both locations, $\Delta$ analyses were suitable to discriminate cotton genotypes. There was a positive correlation between $\Delta$ and seed-cotton yield in SHGO, where water deficit was more severe. In this site, the negative correlations found between $\Delta$ and fiber percentage indicate an integrative effect of gas exchange on $\Delta$ and its association with yield components. As for root robustness and growth kinetic, the GO 05809 genotype performance contributes to sustain the highest values of $\Delta$ found in MONT, where edaphoclimatic conditions were more suitable for cotton. The use of $\Delta$ analysis as a phenomic facility can help to select cotton genotypes, in order to obtain plants with higher efficiency for gas exchange and water use.
\end{abstract}

Index terms: Gossypium, carbon isotope discrimination, genetic breeding, phenotyping.

\section{Fracionamento isotópico do carbono na seleção de genótipo de algodoeiro}

Resumo - O objetivo deste trabalho foi avaliar o fracionamento isotópico do carbono como facilidade fenômica para a seleção de algodoeiro em ambientes contrastantes e analisar a sua correlação com os componentes de rendimento. Foram conduzidos experimentos em blocos ao acaso, com quatro repetições, em Santa Helena de Goiás (SHGO) e Montividiu (MONT), GO. A análise da discriminação isotópica do carbono $(\Delta)$ foi realizada em 15 linhagens e três cultivares. Em seguida, foram determinadas a cinética de crescimento e a arquitetura do sistema radicular a partir de genótipos selecionados anteriormente. Em ambas as localidades, as análises de $\Delta$ mostraram-se adequadas para discriminar os genótipos de algodoeiro. Houve correlação positiva entre $\Delta \mathrm{e}$ a produtividade de algodão em caroço em SHGO, onde o deficit hídrico foi mais severo. Neste local, as correlações negativas encontradas entre $\Delta \mathrm{e}$ a percentagem de fibras indicam um efeito integrativo de trocas gasosas sobre $\Delta$ e sua associação com componentes de rendimento. Quanto à robustez e à cinética de crescimento do sistema radicular, o desempenho do genótipo GO 05809 contribui para sustentar os maiores valores de $\Delta$ encontrados em MONT, onde as condições edafoclimáticas foram mais adequadas para o algodoeiro. O uso da análise de $\Delta$ como facilidade fenômica pode auxiliar a seleção de genótipos de algodoeiro, para a obtenção de plantas com maior eficiência quanto à troca gasosa e ao uso da água.

Termos para indexação: Gossypium, discriminação isotópica do carbono, melhoramento genético, fenotipagem.

\section{Introduction}

Cotton is one of the most important fiber crops, grown in 35 million hectares in the tropical and temperate latitudes, from $47^{\circ} \mathrm{N}$ in Ukraine and $37^{\circ} \mathrm{N}$ in the United States to $32^{\circ} \mathrm{S}$ in South America and Australia (Stewart et al., 2010). In Brazil, about 1.2 million hectares are annually grown with cotton, approximately $90 \%$ of which is located in the Cerrado region - the Brazilian savanna biome (Companhia 
Nacional do Abastecimento, 2013). In this biome, the water deficiency occurrence is a common event from March to May, particularly during cotton reproductive final phase for those sowing carried out at December named by farmers as the "first growth season". For those sowing procedures fulfilled until final January (second growth season), the risks of a severe occurrence of water deficit are very much increased for cotton initial reproductive phase. In most of these areas, water deficit historically initiates in March and intensifies in April, coinciding with cotton first flowering emission and early cotton boll development phase, when cotton plant demand for water is significantly increased (Belot \& Campelo Júnior, 2010). In the last three growth seasons (2009-2010, 2010-2011 and 2011-2012), lint yield was reduced by approximately $30 \%$, due to the occurrence of water deficiency during the reproductive phase in the second growth season areas. Therefore, the development of tools and approaches for cotton phenotyping is an important first step in any breeding program aiming at the selection for plants with more yield components stability or water use efficiency (WUE) under unfavorable conditions (Lopes et al., 2012; Pask \& Reynolds, 2013).

Different breeding methods and selection approaches have been used for this purpose, involving progeny rows, individual selection, crossing and backcrossing, physiology, and molecular marker approaches (SNP, SSR, AFLP, large-scale sequencing etc.) for mapping and genetic association studies (Tuberosa et al., 2011). However, for the selection of plants with high-performing yield components, when plants are grown under unfavorable conditions including water deficiency, the time-consuming mapping of quantitative traits, such as yield and stress tolerance, is difficult because genotypes are never unambiguously inferred from the phenotype. Additionally, estimating WUE relies either on long-term measurements of plant-water consumption or assessments of biomass production; and these large-scale approaches are not feasible in individual plant screening efforts (Blum, 2009; Brito et al., 2011; Tuberosa et al., 2011). As a complementary selection strategy, carbon isotope discrimination $(\Delta)-$ an indirect indicator for WUE (Farquhar et al., 1989; Brito et al., 2011; Elazab et al., 2012) that correlates closely with water deficit tolerance (Centritto et al., 2009) - can be used as a phenomic facility for plant selection procedures under field condition, saving cost and time-consuming in expensive testing in cotton breeding programs. As it has been extensively established, the link between $\Delta$ and WUE is predicated on the concept that both are functionally dependent on intercellular $\mathrm{CO}_{2}$ concentration $\left(\mathrm{c}_{\mathrm{i}}\right.$ ) (Farquhar et al., 1989). Additionally, it has been established that the extent to which $\mathrm{C}_{3}$ plants discriminate against ${ }^{13} \mathrm{C}$ during carbon assimilation can determine their WUE. Thus, $\Delta$ use could reduce the amount of time required by traditional approaches in cotton breeding programs, allowing of the selection of genotypes for high-performing yield components and water use efficiency in cotton plants growing under contrasting environments. Therefore, $\Delta$ could help cotton breeders to rapidly identify these lines using an integrative plant response, which is a major bottleneck for field-plant phenotyping procedures.

The objective of this work was to evaluate the carbon isotope fractionation as a phenomic facility for cotton selection in contrasting environments and to assess its relationship with yield components.

\section{Materials and Methods}

The experiments were carried out in Santa Helena de Goiás (SHGO), GO (17 $48^{\prime} 49^{\prime \prime} \mathrm{S} ; 50^{\circ} 35^{\prime} 49^{\prime \prime} \mathrm{W}$, at $563 \mathrm{~m}$ altitude, sowing on January 27, 2010), and in

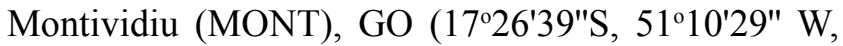
at $940 \mathrm{~m}$ altitude, sowing on January 23, 2010), which represent contrasting environments in the Brazilian savanna, as for altitude, temperature, rain accumulation and distribution (Table 1). Before cotton planting, these areas were cultivated with Sorghum bicolor (L.) Moench, and their soil chemical data are shown in Table 2. Both in SHGO and MONT, the first flower emerged at 57 (on March 25, 2010) and 62 (on March 26, 2010) days after sowing, respectively. After the first flower emission, 72 (SHGO) and $137 \mathrm{~mm}$ (MONT) rainfalls accumulated until cutout (cessation of new vegetative and reproductive growth).

Fifteen cotton breeding lines - CNPA BA 2006-92, CNPA GO 2006-423, CNPA GO 2006-174, CNPA BA 2005-3008, CNPA GO 2007-592, CNPABA2005-3300, CNPA GO 2007-545, CNPA BA 2005-3089, CNPA GO 2007-419, CNPA BA 2005-2481, CNPA GO 2007-630, CNPA BA 2004-2938, CNPA GO 2007-421, CNPA BA 2005-2614, and CNPA GO 2007-424 - and three cultivars - BRS 269, FMT 701, and Delta Opal - were 
sown during the second growth season, in a randomized complete block design, with four replicates, for both locations. 'BRS 269', 'FMT 701', and 'Delta Opal' were chosen as reference, considering their importance in the crop system in the Cerrado region and their similar cycle. The plot size was four rows by $5 \mathrm{~m}$ with $0.45 \mathrm{~m}$ row spacing and 9 plants $\mathrm{m}^{-1}$ density. Starter fertilizer (04-30-16 of N- $\mathrm{P}_{2} \mathrm{O}_{5}-\mathrm{K}_{2} \mathrm{O}$ plus $0.4 \%$ boron and zinc) at $300 \mathrm{~kg} \mathrm{ha}^{-1}$ was band-applied adjacent to each row at planting. Cotton was side-dressed with 20-00-30 of $\mathrm{N}-\mathrm{P}_{2} \mathrm{O}_{5}-\mathrm{K}_{2} \mathrm{O}$ plus $0.3 \%$ boron at $200 \mathrm{~kg} \mathrm{ha}^{-1}$ at square initiation. Weed and insect control were performed according to cotton crop recommendations for the Brazilian savanna (Freire, 2011).

To determine whether $\Delta$ could be used as a phenomic facility, in the conditions of this experiment, $\Delta$ analysis was performed on the bulk of 10 randomly chosen plants per plot. The first youngest fully expanded leaves were sampled at 95 days after sowing (at the boll development phase), with the two sites sampled at 23 days and 16 days after the occurrence of the last rainfall in SHGO and MONT, respectively. Subsequently, leaves were oven-dried and ground to a fine powder for analysis of carbon isotope composition $\left(\delta^{13} \mathrm{C}\right)$ and $\Delta$, according to Farquhar et al., 1989. For this purpose, $\delta$ ${ }^{13} \mathrm{C}$ analysis was carried out using a mass spectrometer (Delta-S Finnigan Mat, Bremen, Germany) at Instituto de Biociências, in the Universidade Estadual de São Paulo, Botucatu, SP, Brazil. The atmospheric isotopic composition was considered to be $-8 \%$ in relation to the international standard, Pee Dee Belemnite (PDB). A second standard calibrated against a fossil belemnite from the Pee Dee formation was used for comparison. The $\Delta$ values were calculated according to Farquhar et al. (1989), by the equation below, in $\delta$ a refers to the atmospheric isotopic composition and $\delta p$ refers to the plant isotopic composition:

$$
\Delta^{13} \mathrm{C}=\frac{\delta \mathrm{ap}-\delta}{1+\frac{\delta \mathrm{p}}{1000}}
$$

At maturity, seed cotton yield, lint yield, fiber percentage, and boll weight were analyzed.

Homogeneity of variances was tested by Bartlett's test. Pearson's correlation coefficient analyses were estimated for all measured variables. Data were subjected to the analysis of variance, and means were grouped using the Scott-Knott grouping method, at 5\%

Table 1. Monthly (2010) and historical mean of maximum and minimum temperatures, and cumulative rainfall, in Santa Helena de Goiás and Montividiu, during cotton growing season.

\begin{tabular}{|c|c|c|c|c|c|c|c|c|c|c|c|c|}
\hline \multirow[t]{3}{*}{ Month } & \multicolumn{6}{|c|}{ Santa Helena de Goiás, GO } & \multicolumn{6}{|c|}{ Montividiu, GO } \\
\hline & \multicolumn{2}{|c|}{$\operatorname{Tmax}\left({ }^{\circ} \mathrm{C}\right)$} & \multicolumn{2}{|c|}{$\operatorname{Tmin}\left({ }^{\circ} \mathrm{C}\right)$} & \multicolumn{2}{|c|}{ Rainfall $(\mathrm{mm})$} & \multicolumn{2}{|c|}{$\operatorname{Tmax}\left({ }^{\circ} \mathrm{C}\right)$} & \multicolumn{2}{|c|}{$\operatorname{Tmin}\left({ }^{\circ} \mathrm{C}\right)$} & \multicolumn{2}{|c|}{ Rainfall (mm) } \\
\hline & Monthly & Hist. & Monthly & Hist. & Monthly & Hist. & Monthly & Hist. & Monthly & Hist. & Monthly & Hist. \\
\hline February & 30.3 & 30.1 & 20.1 & 19.4 & 187 & 208 & 27.1 & 30.6 & 18.9 & 20.1 & 378 & 186 \\
\hline March & 32.0 & 30.1 & 20.9 & 19.4 & 185 & 213 & 28.6 & 30.6 & 17.5 & 20.0 & 180 & 210 \\
\hline April & 30.5 & 29.2 & 17.5 & 17.9 & 51 & 71 & 27.9 & 29.8 & 14.7 & 18.3 & 48 & 119 \\
\hline May & 29.5 & 28.4 & 13.9 & 16.4 & 0 & 28 & 27.1 & 29.2 & 12.2 & 16.8 & 37 & 38 \\
\hline June & 29.8 & 27.8 & 11.6 & 14.7 & 5 & 13 & 26.8 & 28.6 & 11.0 & 14.9 & 32 & 19 \\
\hline July & 30.8 & 28.0 & 12.5 & 14.1 & 1 & 7 & 28.0 & 28.8 & 11.0 & 14.1 & 27 & 8 \\
\hline August & 32.1 & 30.7 & 11.0 & 15.7 & 0 & 13 & 29.8 & 31.4 & 19.4 & 15.7 & 0 & 22 \\
\hline
\end{tabular}

Monthly mean; Hist., historical mean (at least twenty-year averages for the two locations).

Table 2. Soil chemical properties from 0-20 cm and 21-40 cm soil depths, in Santa Helena de Goiás and Montividiu.

\begin{tabular}{|c|c|c|c|c|c|c|c|c|c|c|c|c|c|c|}
\hline \multirow{2}{*}{$\begin{array}{l}\text { Depth } \\
\text { (cm) }\end{array}$} & \multirow{2}{*}{$\underset{\left(\mathrm{g} \mathrm{dm}^{-3}\right)}{\mathrm{SOM}}$} & \multirow{2}{*}{$\begin{array}{c}\mathrm{pH} \\
\mathrm{CaCl}_{2}\end{array}$} & $\mathrm{P}^{*}$ & $\mathrm{~K}^{+}$ & $\mathrm{S}$ & $\mathrm{Ca}^{2+}$ & $\mathrm{Mg}^{2+}$ & $\mathrm{Al}^{3+}$ & CEC & \multirow{2}{*}{$\begin{array}{l}\mathrm{V} \\
(\%)\end{array}$} & B & $\mathrm{Cu}$ & Mn & $\mathrm{Zn}$ \\
\hline & & & \multicolumn{7}{|c|}{--------( $\left(\mathrm{mg} \mathrm{dm}^{-3}\right)$-------- } & & \multicolumn{4}{|c|}{ 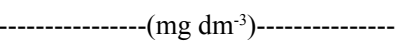 } \\
\hline & \multicolumn{14}{|c|}{ Santa Helena de Goiás } \\
\hline $0-20$ & 32 & 5.2 & 6.8 & 64 & 29 & 3.5 & 1.0 & 0.0 & 8.0 & 58.5 & 0.19 & 1.5 & 46.7 & 1.2 \\
\hline \multirow[t]{2}{*}{$21-40$} & 24 & 5.1 & 0.5 & 33 & 54 & 1.7 & 0.4 & 0.0 & 6.3 & 34.7 & 0.18 & 2.1 & 28.5 & 0.1 \\
\hline & \multicolumn{14}{|c|}{ Montividiu } \\
\hline $0-20$ & 44 & 5.1 & 16.3 & 162 & 8 & 4.1 & 1.0 & 0.1 & 10.7 & 51.4 & 0.47 & 2.9 & 26.4 & 10.3 \\
\hline $21-40$ & 35 & 5.1 & 2.1 & 132 & 37 & 2.9 & 0.7 & 0.0 & 8.3 & 47.2 & 0.44 & 1.5 & 13.9 & 3.9 \\
\hline
\end{tabular}

SOM, soil organic matter; $\mathrm{V}$, base saturation; CEC, cation exchange capacity. $\mathrm{P}^{*}$ was extracted using Mehlich-1 solution; and $\mathrm{pH}$ was measured in water. 
probability (Scott \& Knott, 1974). Analyses were done using the SAS System ver. 9.1.3 (SAS Institute, Cary, NC, USA).

Based on $\triangle$ performance of CNPA GO 2005809 (GO 05 809) under field condition, this genotype was chosen for subsequent studies on its root growth kinetic and root system architecture. These traits were considered important for edaphoclimatic conditions prevailing in the Brazilian savannah biome, where distinct wet and dry seasons occur, concentrating $90 \%$ of the mean annual rainfall from November to February, associate to deeper soils and robustness of cotton root characteristics. Therefore, evaluating root growth kinetic and root architecture can to improve our understanding about the responses of GO 05 809 genotype as for $\Delta$ found under field conditions. For this purpose, in addition to the genotypes used as reference (BRS 269 and FMT 701), 'Guazuncho II' was included as a tolerant genotype check, and a greenhouse experiment was carried out at Embrapa experimental station, in Santo Antonio de Goiás, GO, Brazil, at day/night temperatures of $28 \pm 2 / 19 \pm 2^{\circ} \mathrm{C}$, using purpose-built root chambers. These chambers consisted of two glass plates $1.20 \mathrm{~m}$ high, $60 \mathrm{~cm}$ wide, and $4 \mathrm{~mm}$ thick, which were separated on three sides by a $1.2 \mathrm{~cm}$ thick aluminum spacer. The chambers were filled with 3,620 g black fine-textured soil, positioned at $27^{\circ}$ inclination, and covered with black fabric to avoid light on soil and roots. This experiment was carried out using a randomized complete block design with five replicates. Before sowing, the chambers were watered until saturation (field capacity), and three seeds per genotype were sowed in the center of each chamber and three days after emergence, seedlings were thinned to one plant. After emergence, $100 \mathrm{~mL}$ of half-strength Hoagland solution was applied twice a week to supply nutrients demand.

At $14,21,28,35$, and 42 days after emergence, the visible root system through clear glass was photographed on both sides of each chamber, with a digital camera of 12 megapixels resolution Sony Cyber Shot DSC-HX1, Optical Zoom 20X, (Sony Tokyo, Japan). The images were analyzed using the WinRHIZO Pro software (Regent Instruments, Quebec, QC, Canada), to determine root growth kinetic and root architecture across a series of variables, such as total root length, total surface area, total volume, and average diameter. At 42 days after emergence, plants were harvested, plant height was measured, and the leaf area was determined using a leaf area meter, model LI-COR 3100C (Biosciences, LI-COR Inc., Lincoln, NE, USA). Shoots were removed by cutting at the stem base; and shoot and root dry weights were determined, after drying at $65^{\circ} \mathrm{C}$ for 72 hours. Data were subjected to the analysis of variance, and means were subjected to Student's t test, at 5\% probability, using the SAS System version 9.1.3 (SAS Institute, Cary, NC, USA).

\section{Results and Discussion}

In both locations, $\Delta$ was able to discriminate between cotton genotypes ( $\mathrm{p}<0.0001$ and 0.0157 for SHGO and MONT, respectively). Highest $\Delta$, seed cotton yield (SCY), lint yield (LY), and boll weight means were obtained in the MONT site (Figures 1 and 2), where the edaphoclimatic conditions were more suitable (lower mean night temperatures and higher rainfall accumulation) for cotton growth and development compared with those plants grown in SHGO site (Tables 1 and 2). For the experiment conducted in SHGO, where water deficiency was more severe during the reproductive phase, there was a significant and positive correlation between $\triangle$ and SCY (Table 3 ).

The positive correlation between $\Delta$ and SCY strongly suggests the existence of genetic variation in root characteristics, such as greater and deeper root mass, which may help plants to maintain relatively higher water status levels, due to an increased capacity of absorbing moisture from this deep soil profile, even under dry conditions. This greater capacity to absorb moisture allows plant to maintain a greater stomatal conductance and a higher rate of

Table 3. Phenotypic correlation among carbon isotope discrimination $\left(\Delta{ }^{13} \mathrm{C}\right)$, seed cotton (SC) yield, fiber percentage, lint yield, and boll weight of 18 cotton genotypes grown in Santa Helena de Goiás (upper diagonal of table) and Montividiu (lower diagonal), during 2010.

\begin{tabular}{lccccc}
\hline Variable & $\begin{array}{c}\Delta^{13} \mathrm{C} \\
(\%)\end{array}$ & $\begin{array}{c}\text { SC yield } \\
\left(\mathrm{kg} \mathrm{ha}^{-1}\right)\end{array}$ & $\begin{array}{c}\text { Fiber } \\
(\%)\end{array}$ & $\begin{array}{c}\text { Lint yield } \\
\left(\mathrm{kg} \mathrm{ha}^{-1}\right)\end{array}$ & $\begin{array}{c}\text { Boll } \\
(\mathrm{g})\end{array}$ \\
\hline$\Delta^{13} \mathrm{C}(\%)$ & - & $0.255^{*}$ & $-0.328^{* *}$ & $0.090^{\mathrm{ns}}$ & $0.090^{\mathrm{ns}}$ \\
SC yield $\left(\mathrm{kg} \mathrm{ha}^{-1}\right)$ & $-0.087^{\mathrm{ns}}$ & - & $-0.050^{\mathrm{ns}}$ & $0.888^{* *}$ & $0.064^{\mathrm{ns}}$ \\
Fiber $(\%)$ & $-0.131^{\mathrm{ns}}$ & $-0.042^{\mathrm{ns}}$ & - & $0.403^{* *}$ & $-0.209^{\mathrm{ns}}$ \\
Lint yield $\left(\mathrm{kg} \mathrm{ha}^{-1}\right)$ & $-0.134^{\mathrm{ns}}$ & $0.926^{\mathrm{ns}}$ & $0.335^{* *}$ & - & $-0.028^{\mathrm{ns}}$ \\
Boll $(\mathrm{g})$ & $0.171^{\mathrm{ns}}$ & $0.192^{\mathrm{ns}}$ & $-0.318^{* *}$ & $0.056^{\mathrm{ns}}$ & - \\
\hline
\end{tabular}

${ }^{n}$ Nonsignificant. $*$ and ${ }^{*}$ Significant at 5 and $1 \%$ probability, respectively. 

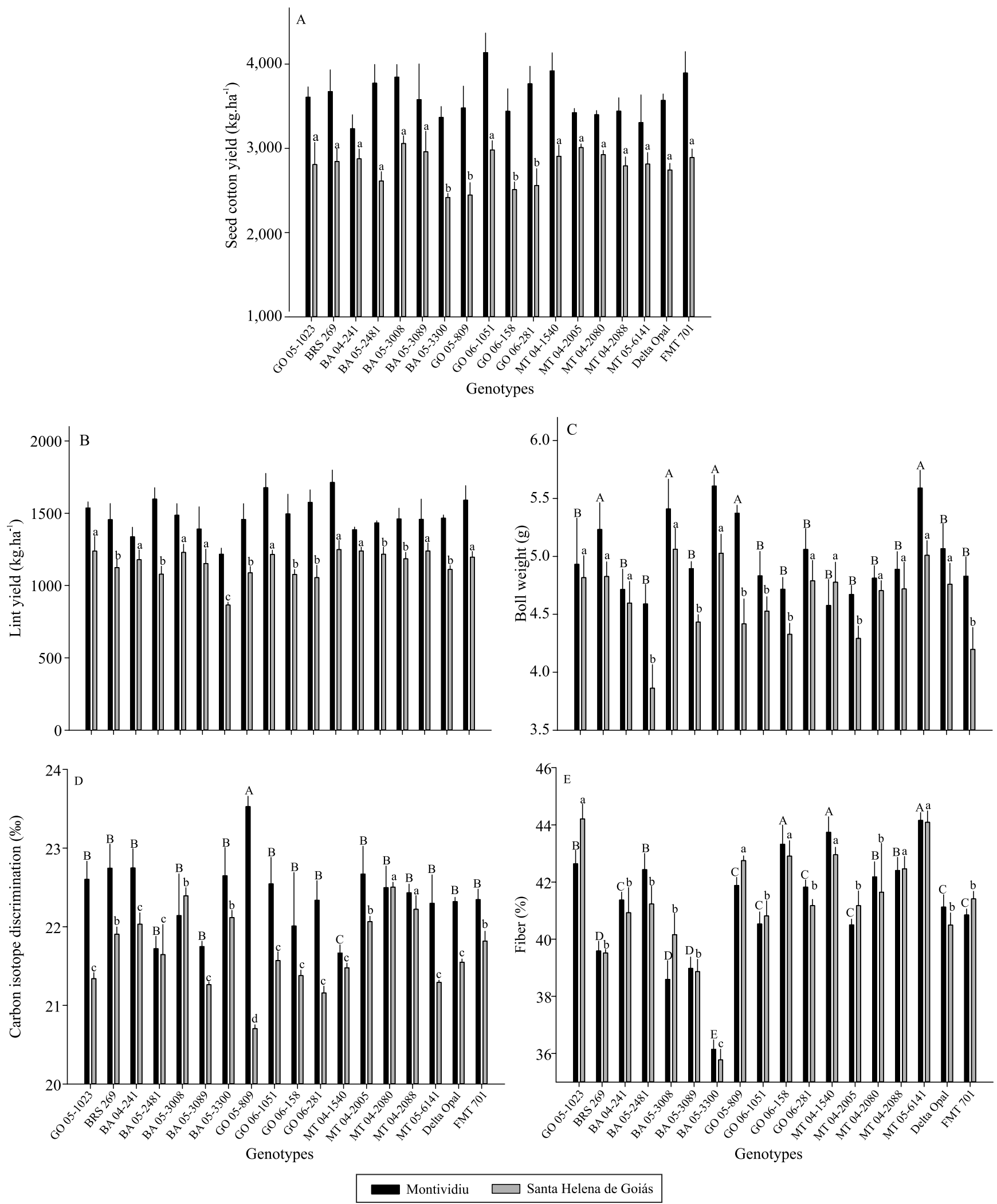

Figure 1. Seed cotton yield (A), lint yield (B), boll weight (C), mean carbon isotope discrimination (D), and fiber percentage (E) for eighteen cotton breeding lines grown in the Brazilian savanna regions of SHGO and MONT sites. Means followed by the same letter in each location do not differ by Scott-Knott test, at 5\% probability. 
$\mathrm{CO}_{2}$ diffusion, increasing the rate of photosynthesis, growth, and, consequently, its yield stability when growing under unfavorable conditions. Although root traits and root growth kinetics have been measured only under controlled conditions (Figures 3 and 4), the performance of GO 05809 for some root parameters - such as total root length, total root volume, surface area, main root length, and root: shoot ratio - clearly indicates its contribution to stomatal conductance
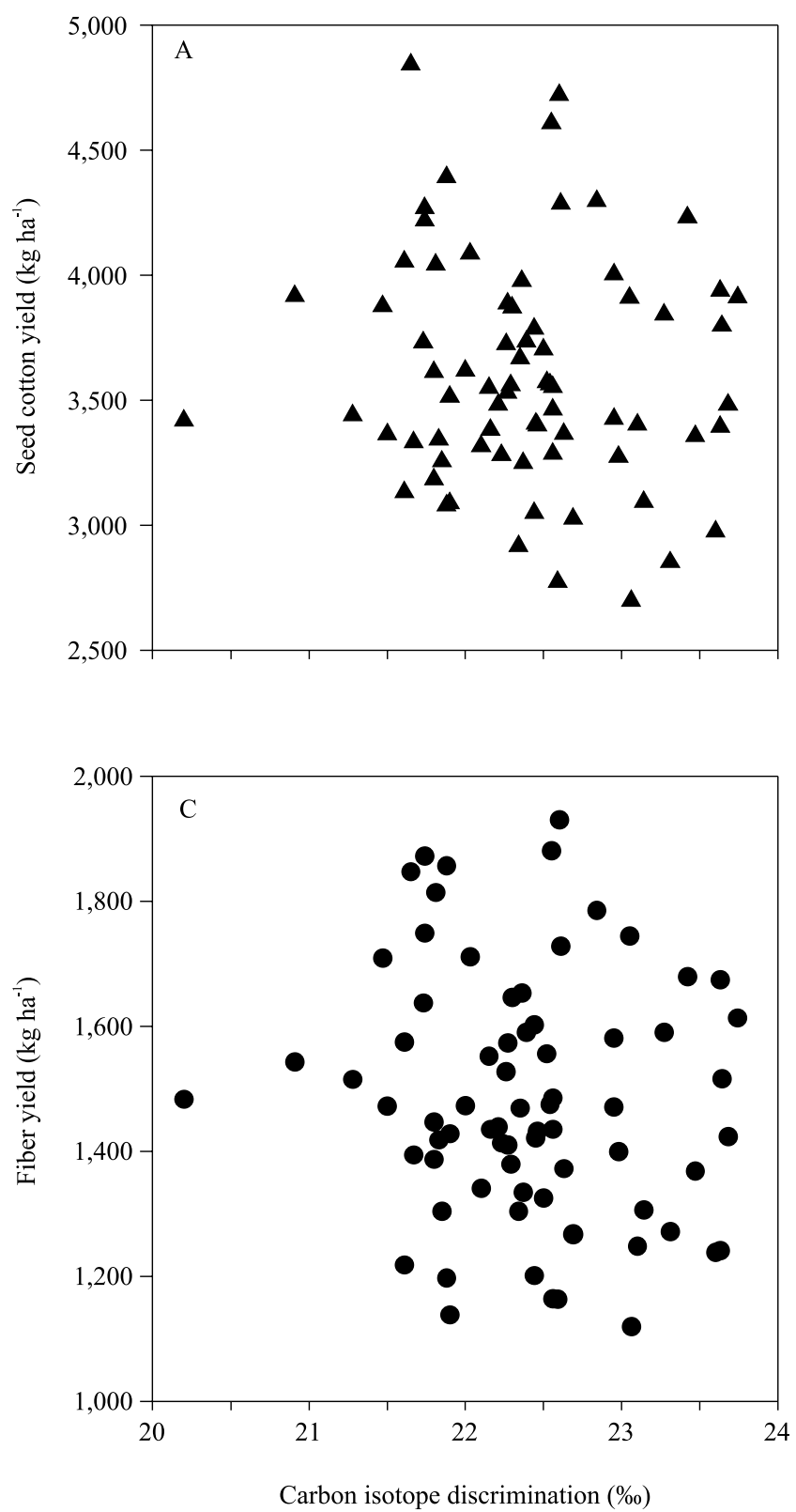

and, consequently, its effects on the highest $\Delta$ values found in MONT site. As it has been shown for wheat, water deficiency decreased stomatal conductance, plant accumulated transpiration, and aerial biomass accumulation, which resulted in an increase in carbon isotope composition (Elazab et al., 2012). In the present work, the negative correlation found between $\Delta$ and fiber percentage in SHGO site indicates that there is an increase in sink power redirecting carbohydrates
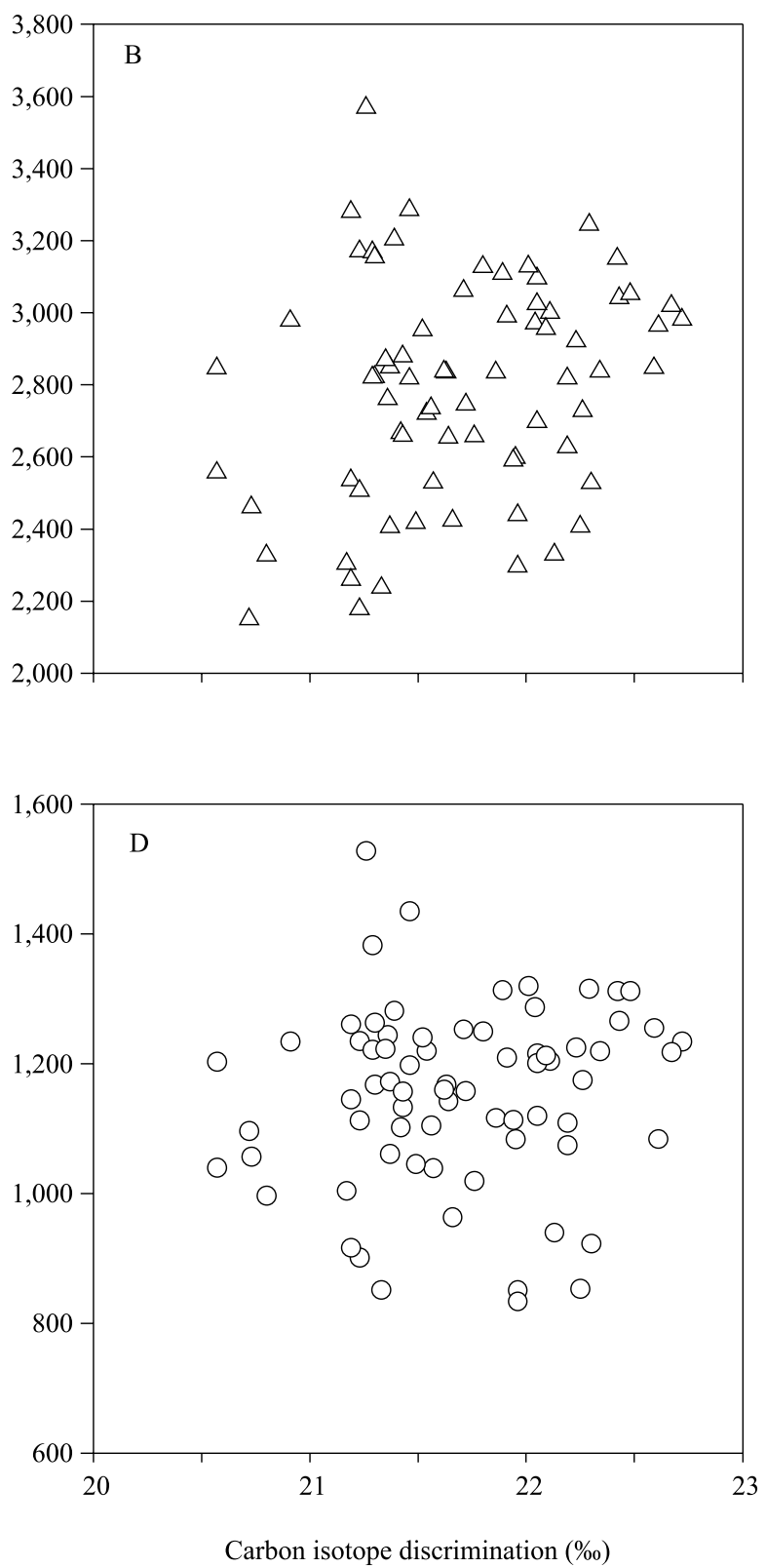

Figure 2. Dispersion diagram showing seed cotton yield and lint yield, as a function of carbon isotope discrimination, for eighteen cotton breeding lines grown in the Brazilian savanna regions of Montividiu and Santa Helena de Goiás sites. 
to seed formation, which is detrimental to fiber formation. In fact, immature seeds and developing fiber are components of cotton ovules and share concurrent and similar phases of their developmental events. By the coincidence of their proximity, fiber and seed formation are competing sinks fed through a common funiculus. During this phase, cellulose microfibrils are added to the wall of the fiber, while oils, proteins, and carbohydrates are deposited in the embryo (Kloth \& Turley, 2010). Transgenic cotton
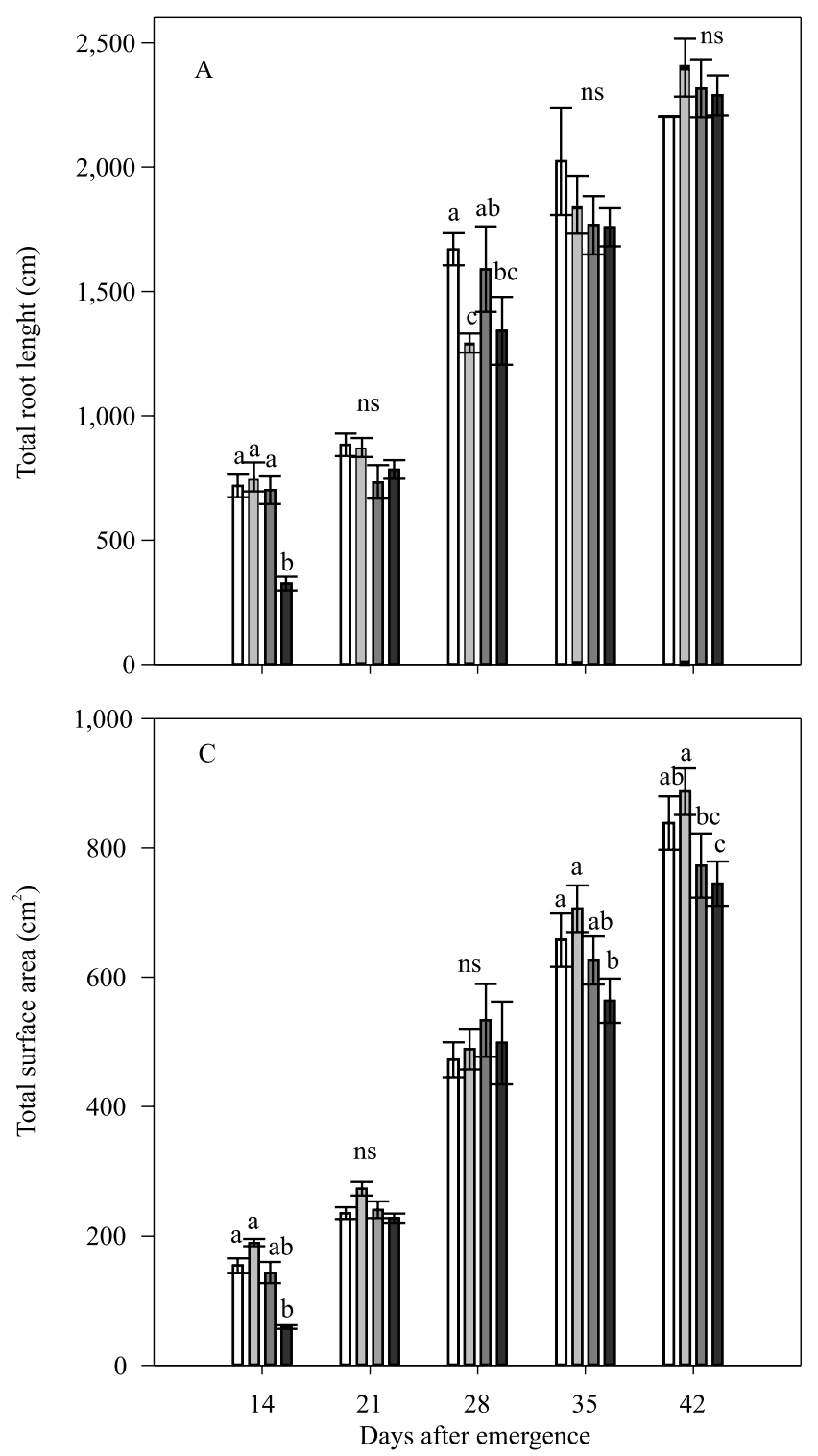

plants expressing increased indole-3-acetic acid levels in the ovule epidermis have increased numbers of lint fibers (Zhang et al., 2011). According to these authors, because there was no difference in seed cotton yield between transgenic lines and the nontransgenic control, the greater lint yield is mainly due to the enhanced lint percentage.

In fact, it is necessary to consider that the advances of cotton productivity have been reached by increasing gas exchange performance in the last decades. To
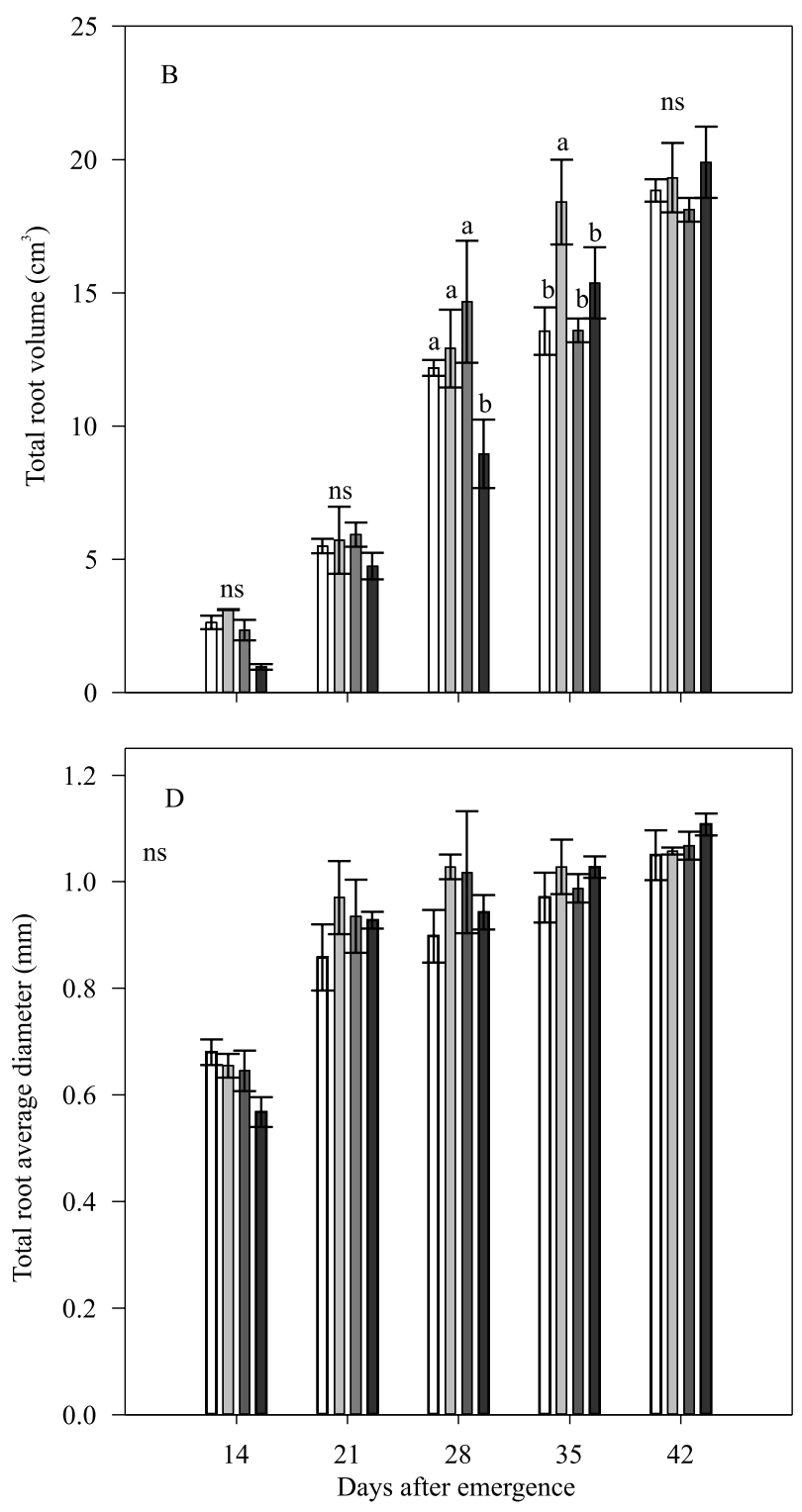

\begin{tabular}{|llll|}
\hline$\square$ Guazuncho II & $\square$ GO 2005-809 $\square$ BRS 269 \\
\hline
\end{tabular}

Figure 3. Root attributes of selected cotton genotypes of Gossypium hirsutum (L.), related to their growth kinetic performance and root architecture variables. Means followed by the same letter in each location do not differ by Scott-Knott test, at 5\% probability. 
enhance productivity of cotton species $G$. hirsutum and $G$. barbadense, in the last 50 years, most breeding programs have focused on increases in the net rate of photosynthesis and tolerance to elevated temperatures by increasing stomatal conductance (Radin et al., 1994; Lu et al., 1998; Zhang et al., 2013). However, from a global warm perspective (Trenberth et al., 2007; Cuadra et al., 2012; Marin et al., 2013; Bowman et al., 2013), breeding programs should redirect their efforts to construct more suitable plants to face challenges in new climate scenarios. In this view, plant breeders and physiologists are concentrating their efforts in the construction of plants not only to survive under abiotic stresses but also to be stable and productive in these hard environments. Scientists should be able to define the best level of "orchestration" of plant morphophysiological mechanisms to improve WUE for plants growing in extreme climate events.

In MONT site, where the edaphoclimatic conditions are more suitable for cotton growth, it is clear the contribution of a root robust system and its fast growth
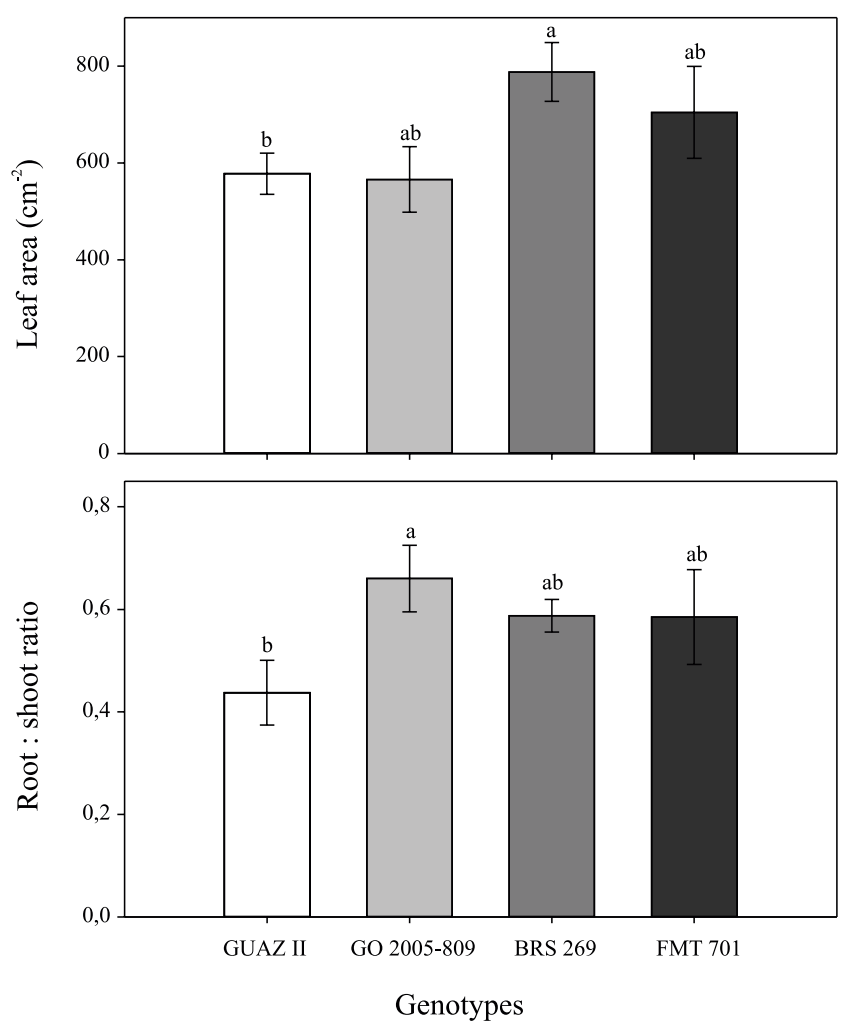

Figure 4. Leaf area and root : shoot ratio attributes of selected cotton genotypes of Gossypium hirsutum (L.) grown under greenhouse conditions. on highest $\Delta$ values, as shown by GO 05809 genotype (Figure $1 \mathrm{D}$ ). Thus, our results support that $\Delta$ could be used as a phenomic facility to help breeders in the selection for root traits associated with fast growth and root robustness for plants grown under moderate water deficit as occurred in this site. Higher positive correlations found between wheat root traits and $\Delta$ values, only on plants grown under suitable environments, support this tendency (Elazab et al., 2012). Additionally, the robustness of root traits shown by GO 05809 was unable to supply water demand in SHGO site, where water deficit was extremely severe (rainfall accumulated was only $72 \mathrm{~mm}$ after first flower emission). In this site, other mechanisms such as cotton shoot architecture, leaf area and particularly stomatal conductance could be acting to support the higher WUE shown by this genotype, as it was indicated by its lowest $\Delta$ values (Figure $1 \mathrm{D}$ ).

As discussed, it is crucial to define the breeding environment-target, since the route to yield-change expressed by crops is different for each geographical location and new growing season, reflecting new combinations and temporal dynamics in the biotic and abiotic environments (Cooper et al., 1997; Chenu et al., 2011). Certainly, the DNA code may carry information that influences alternate plant responses to each new environment, but the way information is integrated throughout the growing season is critically determinant for crop yield at the physiological level and across the community of plants (Rebetzke et al., 2013). In this sense, field physiological evaluations of the germplasm performance for abiotic stress, as well as water and heat constraints are challenging. Field environments are unpredictable and genotype by environment interactions are difficult to interpret, if the environment target is not well characterized. As a result, there are limited breeding program advances, since that is a challenging bottleneck for a good field screening to select for a specific trait. The use of physiological traits such as $\Delta$ could help the breeding programs in the characterization of target environments, considering the performance of a certain genotype according to its interaction in each environment. The wide $\Delta$ variation shown by GO 05809 genotype in both sites strongly supports the above argument, allowing breeders to select a genotype for each target environment, considering plant versus environment interactions for a specific trait, such as better performance for water use 
efficiency showed by GO 05809 in the hard location (SHGO) via that proxy.

Under field conditions, measurements of root characteristics are not feasible at a large scale and use destructive methods, which limits their use in breeding programs (Ullah et al., 2008). The adoption of indirect screening methods which use integrative variables, such as $\Delta$, can make selection feasible at a large scale for cotton plants with high-performing yield components under water deficiency, or for cotton germplasm with more robust root systems. However, it is very important to consider that more selection studies relating crop performance to $\Delta$ also need to be performed using the progeny of crosses which are specifically constructed for this purpose. These studies should be performed in different environments, with different soil characteristics, considering that there are several critical areas of research which need to be addressed, if $\Delta$ potential as an indicator of that variation is to be effectively exploited.

\section{Conclusions}

1. Carbon isotope discrimination $(\Delta)$ is able to discriminate cotton genotypes in contrasting environments that represent cotton production areas in the Brazilian savannah.

2. Cotton breeders can use $\Delta$ values as a phenomic facility to help in the plant selection, in order to obtain plants with higher efficiency for gas exchange and water use under unfavorable conditions.

\section{Acknowledgements}

To Embrapa Algodão, for laboratory and personnel infrastructure; and to Fundação de Apoio à Pesquisa e Desenvolvimento Agropecuário de Goiás, for support in implementing and carrying out the field experiments.

\section{References}

BELOT, J.L.; CAMPELO JÚNIOR, J.H. Época de plantio para o cultivo adensado do algodoeiro em Mato Grosso. In: O SISTEMA de cultivo do algodoeiro adensado em Mato Grosso: embasamento e primeiros resultados: atas do workshop de Cuiabá. Cuiabá: Defanti, 2010. p.95-120.

BLUM, A. Effective use of water (EUW) and not water-use efficiency (WUE) is the target of crop yield improvement under drought stress. Field Crops Research, v.112, p.119-123, 2009. DOI: $10.1016 /$ j.fcr.2009.03.009.
BOWMAN, M.J.; PARK, W.; BAUER, P.J.; UDALL, J.A.; PAGE, J.T.; RANEY, J.; SCHEFFLER, B.E.; JONES, D.C.; CAMPBELL, B.T. RNA-seq transcriptome profiling of upland cotton (Gossypium hirsutum L.) root tissue under water-deficit stress. PLOS ONE, v.8, p.e82634, 2013. DOI: 10.1371/journal.pone.0082634.

BRITO, G.G. de; SOFIATTI, V.; LIMA, M.M. de A.; CARVALHO, L.P. de; SILVA FILHO, J.L. da. Physiological traits for drought phenotyping in cotton. Acta Scientiarum. Agronomy, v.33, p.117-125, 2011. DOI: 10.4025/actasciagron.v33i1.9839.

CENTRITTO, M.; LAUTERI, M.; MONTEVERDI, M.C.; SERRAJ, R. Leaf gas exchange, carbon isotope discrimination, and grain yield in contrasting rice genotypes subjected to water deficits during the reproductive stage. Journal of Experimental Botany, v.60, p.2325-2339, 2009. DOI: 10.1093/jxb/erp123.

CHENU, K.; COOPER, M.; HAMMER, G.L.; MATHEWS, K.L.; DRECCER, M.F.; CHAPMAN, S.C. Environment characterization as an aid to wheat improvement: interpreting genotype-environment interactions by modelling water-deficit patterns in North-Eastern Australia. Journal of Experimental Botany, v.62, p.1743-1755, 2011. DOI: $10.1093 /$ jxb/erq459.

COMPANHIA NACIONAL DE ABASTECIMENTO. Séries históricas. 2013. Disponível em: <www.conab.gov.br/conteudos. php? $\mathrm{a}=1252 \& \mathrm{t}=>$. Acesso em: 5 dez. 2013.

COOPER, M.; STUCKER, R.E.; DELACY, I.H.; HARCH, B.D. Wheat breeding nurseries, target environments, and indirect selection for grain yield. Crop Science, v.37, p.1168-1176, 1997. DOI: $10.2135 /$ cropsci1997.0011183X003700040024x.

CUADRA, S.V.; COSTA, M.H.; KUCHARIK, C.J.; DA ROCHA, H.R.; TATSCH, J.D.; INMAN-BAMBER, G.; DA ROCHA, R.P.; LEITE, C.C.; CABRAL, O.M.R. A biophysical model of sugarcane growth. Global Change Biology Bioenergy, v.4, p.36-48, 2012. DOI: 10.1111/j.1757-1707.2011.01105.x.

ELAZAB, A.; MOLERO, G.; SERRET, M.D.; ARAUS, J.L. Root traits and delta $13 \mathrm{C}$ and $\mathrm{d} 18 \mathrm{O}$ of durum wheat under different water regimes. Functional Plant Biology, v.39, p.379-393, 2012. DOI: $10.1071 /$ FP11237.

FARQUHAR, G.D.; EHLERINGER, J.R.; HUBICK, K.T. Carbon isotope discrimination and photosynthesis. Annual Review of Plant Physiology and Plant Molecular Biology, v.40, p.503-537, 1989. DOI: 10.1146/annurev.pp.40.060189.002443.

FREIRE, E.C. Algodão no Cerrado do Brasil. 2.ed. Aparecida de Goiânia: Associação Brasileira dos Produtores de Algodão, 2011. 1082p.

KLOTH, R.H.; TURLEY, R.B. Physiology of seed and fiber development. In: STEWART, J.M.; OOSTERHUIS, D.M.; HEITHOLT, J.J.; MAUNEYET, J.R. (Ed.). Physiology of cotton. New York: Springer, 2010. DOI: 10.1007/978-90-481-3195-2_11.

LOPES, M.S.; REYNOLDS, M.P.; JALAL-KAMALI, M.R.; MOUSSA, M.; FELTAOUS, Y.; TAHIR, I.S.A.; BARMA, N.; VARGAS, M.; MANNES, Y.; BAUM, M. The yield correlations of selectable physiological traits in a population of advanced spring wheat lines grown in warm and drought environments. Field Crops Research, v.128, p.129-136, 2012. DOI: 10.1016/j. fcr.2011.12.017.

LU, Z.M.; PERCY, R.G.; QUALSET, C.O.; ZEIGER, E. Stomatal conductance predicts yields in irrigated Pima cotton and bread wheat 
grown at high temperatures. Journal of Experimental Botany, v.49, p.453-460, 1998. DOI: 10.1093/jxb/49.Special_Issue.453.

MARIN, F.R.; JONES, J.W.; SINGELS, A.; ROYCE, F.; ASSAD, E.D.; PELLEGRINO, G.Q.; JUSTINO, F. Climate change impacts on sugarcane attainable yield in Southern Brazil. Climatic Change, v.117, p.227-239, 2013. DOI: 10.1007/ s10584-012-0561-y.

PASK, A.J.D.; REYNOLDS, M.P. Breeding for yield potential has increased deep soil water extraction capacity in irrigated wheat. Crop Science, v.53, p.2090-2104, 2013. DOI: 10.2135/ cropsci2013.01.0011.

RADIN, J.W.; LU, Z.M.; PERCY, R.G.; ZEIGER, E. Genetic-variability for stomatal conductance in Pima cotton and its relation to improvements of heat adaptation. Proceedings of the National Academy of Sciences of the United States of America, v.91, p.7217-7221, 1994. DOI: 10.1073/pnas.91.15.7217.

REBETZKE, G.J.; CHENU, K.; BIDDULPH, B.; MOELLER, C.; DEERY, D.M.; RATTEY, A.R.; BENNETT, D.; BARRETT-LENNARD, E.G.; MAYER, J.E. A multisite managed environment facility for targeted trait and germplasm phenotyping. Functional Plant Biology, v.40, p.1-13, 2013. DOI: 10.1071/ FP12180.

SCOTT, A.J.; KNOTT, M. A cluster analysis method for grouping means in the analysis of variance. Biometrics, v.30, p.507-512, 1974. DOI: $10.2307 / 2529204$.

STEWART, J.M.; OOSTERHUIS, D.M.; HEITHOLT, J.J.; MAUNEY, J.R. (Ed.). Physiology of cotton. New York: Springer, 2010. DOI: 10.1007/978-90-481-3195-2.
TRENBERTH, K.E.; JONES, P.D.; AMBENJE, P.; BOJARIU, R.; EASTERLING, D.; KLEIN TANK, A.; PARKER, D.; RAHIMZADEH, F.; RENWICK, J.A.; RUSTICUCCI, M.; SODEN, B.; ZHAI, P. Observations: surface and atmospheric climate change. In: SOLOMON, S.; QIN, D.; MANNING, M.; CHEN, Z.; MARQUIS, M.; AVERTY, K.B.; TIGNOR, M.; MILLER, H.L. (Ed.). Climate change 2007: the physical science basis: contribution of Working Group I to the Fourth Assessment Report of the Intergovernmental Panel on Climate Change. Cambridge: Cambridge University, 2007.

TUBEROSA, R.; GRANER, A.; VARSHNEY, R.K. Genomics of plant genetic resources: an introduction. Plant Genetic Resources: Characterization and Utilization, v.9, p.151-154, 2011. DOI: 10.1017/S1479262111000700.

ULLAH, I.; RAHMAN, M.; ASHRAF, M.; ZAFAR, Y. Genotypic variation for drought tolerance in cotton (Gossypium hirsutum L.): leaf gas exchange and productivity. Flora, v.203, p.105-115, 2008. DOI: $10.1016 /$ j.flora.2007.12.001.

ZHANG, M.; ZHENG, X.L.; SONG, S.Q.; ZENG, Q.W.; HOU, L.; LI, D.M.; ZHAO, J.; WEI, Y.; LI, X.B.; LUO, M.; XIAO, Y.H.; LUO, X.Y.; ZHANG, J.F.; XIANG, C.B.; PEI, Y. Spatiotemporal manipulation of auxin biosynthesis in cotton ovule epidermal cells enhances fiber yield and quality. Nature Biotechnology, v.29, p.453-458, 2011. DOI:10.1038/nbt.1843.

ZHANG, T.; QIAN, N.; ZHU, X.; CHEN, H.; WANG, S.; MEI, H.; ZHANG, Y. Variations and transmission of QTL alleles for yield and fiber qualities in upland cotton cultivars developed in China. PLoS One, v.8, e57220, 2013. DOI: 10.1371/journal. pone. 0057220 .

Recebido em 15 de novembro de 2013 e aprovado em 27 de agosto de 2014 